\title{
The effectiveness of NEPA in the prevention of chemotherapy-induced nausea vomiting among chemo naive patients in an Indian setting
}

Bharat Vaswani ${ }^{1}$, Palanki Satya Dattatreya ${ }^{2}$, Sagar Bhagat ${ }^{3^{*}}$ (D) Saiprasad Patil ${ }^{3}$ and Hanmant Barkate ${ }^{3}$

\begin{abstract}
Background: Chemotherapy induced nausea- vomiting (CINV) is considered as the most common, feared and most troublesome side effect of chemotherapy. NEPA (NEtupitant $300 \mathrm{mg}+$ PAlonosetron $0.50 \mathrm{mg}$ ) is the first commercially available oral fixed-dose combination (FDC) of two active antiemetic agents in India. The present study was planned to evaluate the effectiveness of NEPA in the real world setting of India.

Methods: This was a multicentric retrospective study conducted in two centers in India. The data of all chemonaive patients, who were prescribed NEPA was analyzed. Effectiveness i.e. complete response and complete protection in controlling overall, acute and delayed phase was analyzed.

Results: A total of 329 patients were enrolled in the study. 260 received highly emetogenic chemotherapy (HEC) regimen and 69 received moderately emetogenic chemotherapy (MEC) regimen. Among all the enrolled patients, complete response in acute, delayed and overall phase was 93, 85.71 and $85.41 \%$ respectively; and completed protection was $88.44,81.76$ and $80.54 \%$ respectively. Those who received HEC regimen, the completed response and complete protection in overall phase was 84.61 and $79.61 \%$ respectively and those who received $\mathrm{MEC}$ regimen the completed response and complete control in overall phase was 84.05 and 84.05\% respectively.

Conclusion: A single oral dose of NEPA targeting dual pathways showed effective control of nausea-vomiting in patients on the HEC and MEC regimens and had good control over nausea-vomiting in acute, delayed and overall phase of nausea-vomiting.
\end{abstract}

Keywords: NEPA, India, Nausea, Vomiting, HEC, MEC

* Correspondence: sagar.bhagat@glenmarkpharma.com

${ }^{3}$ Medical Services, IF, Glenmark Pharmaceutical limited, B D Sawant Road,

Andheri [East], Mumbai 400099, India

Full list of author information is available at the end of the article

C The Author(s). 2021 Open Access This article is licensed under a Creative Commons Attribution 4.0 International License, which permits use, sharing, adaptation, distribution and reproduction in any medium or format, as long as you give appropriate credit to the original author(s) and the source, provide a link to the Creative Commons licence, and indicate if changes were made. The images or other third party material in this article are included in the article's Creative Commons licence, unless indicated otherwise in a credit line to the material. If material is not included in the article's Creative Commons licence and your intended use is not permitted by statutory regulation or exceeds the permitted use, you will need to obtain permission directly from the copyright holder. To view a copy of this licence, visit http://creativecommons.org/licenses/by/4.0/. The Creative Commons Public Domain Dedication waiver (http://creativecommons.org/publicdomain/zero/1.0/) applies to the data made available in this article, unless otherwise stated in a credit line to the data. 


\section{Background}

In spite of many targeted and biological therapies available in the treatment of various cancers, chemotherapy is still considered the cornerstone in the management algorithm. Unfortunately, side effects due to chemotherapies continue to affect the quality of life of patients. Chemotherapy induced nausea- vomiting (CINV) is one such, which is considered the most common, feared and most troublesome side effect [1]. Decades after discovering the first antiemetic against CINV [2], CINV is still considered the oncologist's nightmare, as more than $40 \%$ patients still experience nausea, vomiting, or both, following the administration of chemotherapy [3]. This may be because of the complex multi-factorial process involved between the receptors and neurotransmitters of the brain and the gastrointestinal tract [4]. With the availability of newer antiemetics, the control over vomiting is substantially good, but nausea, especially in the delayed phase $(24-120 \mathrm{~h})$, still continues to be bigger challenge and the unmet need in the present era [5]. The biggest barrier highlighted for the uncontrolled nausea /vomiting is poor adherence to the guidelines, as many studies have suggested that patients receiving chemotherapy do not receive guideline-backed antiemetics [6-8].

NEPA (NEtupitant $300 \mathrm{mg}$ + PAlonosetron $0.50 \mathrm{mg}$ ) is the first commercially available oral fixed-dose combination [FDC] of two active antiemetic agents in India. Netupitant is a new, highly selective NK1RA and palonosetron is a "second-generation" 5-HT3 RA with a longer half-life, as compared to ondansetron, granisetron. The combination has the potential to improve the guideline adherence by targeting two critical pathways involved in the emesis, with a convenient, single oral dose thereby potentially improving treatment compliance, which in turn could improve CINV control. The safety and efficacy of NEPA was evaluated in three pivotal trials, and was found to be well tolerated and safe when used as prophylaxis for acute and delayed CINV [9-11].

Since there is a country specific variation in the response rate to antiemetics prescribed to patients, as highlighted by the multination study (PrACTICE) [6], there was the need to have India specific data, as there was no data on the effectiveness of NEPA in the Indian setting.

Hence the present study was planned to evaluate the effectiveness of NEPA in the real world setting of India.

\section{Methods}

This was a multicentric retrospective study conducted in two centres in India, among 329 patients, after taking approval from the ethics committee. The data of all the chemonaive patients, who were prescribed NEPA prophylactically before first cycle of chemotherapy, and those with a complete data of responses in relation to the control of nausea-vomiting, were analysed in the study. Treatment with Dexamethasone was given as per the treating oncologist preference, which was mostly as $12 \mathrm{mg}$ IV on day 1 (day of chemotherapy) followed by 8 mg BD from day 2 to 4 in patients on HEC and MEC regimen. The responses recorded were the presence or absence of vomiting and nausea. The severity of the nausea was recorded in a visual analogue scale (VAS of 10 $\mathrm{mm}$ ). Nausea grading $<2.5 \mathrm{~mm}$ was considered as no significant nausea (NSN). Data was recorded in a predesigned pro-forma and compiled in Microsoft excel version 2015 and analysed. Descriptive statistics for quantitative variables was represented as mean +/- SD. Qualitative variables (CR and $\mathrm{CP}$ ) was represented as frequency \& percentages.

The following definitions were used for analysing the data:

- Overall complete response (CR-O), defined as no vomiting and no need for rescue medication, at cycle 1 (Time frame: $0-120 \mathrm{~h}$ )

- Complete response during acute phase (CR-AP), defined as no vomiting and no need for rescue medication, at cycle 1 (Time frame: $0-24 \mathrm{~h}$ ) and

- Complete response during delayed phase (CR-DP), defined as no vomiting and no need for rescue medication, at cycle 1 (Time frame: 24-120 h)

- Overall complete protection (CP-O), defined as no significant ( $<2.5 \mathrm{~mm}$ on VAS) nausea, no vomiting and no use of rescue medication. (Time frame: 0$120 \mathrm{~h}$ )

- No nausea - Complete absence of nausea (VAS score 0)

\section{Result}

A total of 329 patients were enrolled in the study. Baseline characteristic showed majority of the patients $(n=$ $119)$ in the age group of 51-60 years, with average age of $53.51 \pm 11.98$ years. Male to female ratio was $0.85: 1$. Breast cancer was the most common diagnosis among the enrolled group. Among the 329 enrolled patients, 260 received a highly emetogenic chemotherapy (HEC) regimen and 69 received a moderately emetogenic chemotherapy (MEC) regimen. The commonly prescribed HEC regimen was cisplatin and anthracyclinecyclophosphamide based, and the commonly prescribed MEC regimen was FOLFOX or FOLFIRI. Among all the enrolled patients $(n=329), \mathrm{CR}-\mathrm{AP}, \mathrm{CR}-\mathrm{DP}$ and CR-O was $93,85.71$ and $85.41 \%$ respectively; whereas completed protection was $88.44,81.76$ and $80.54 \%$ in acute, delayed and overall phase respectively. (Tables 1 and 2).

Among those who received HEC regimen $(n=260)$, CR-AP, CR-DP and CR-O was 89.61, 85.76 and $84.61 \%$ 
Table 1 Complete response among enrolled patients

\begin{tabular}{llll}
\hline Phases & \multicolumn{3}{l}{ Complete response (\%) } \\
\cline { 2 - 4 } & $\begin{array}{l}\text { Enrolled patients } \\
(\mathbf{n = 3 2 9 )}\end{array}$ & HEC $(\mathbf{n}=\mathbf{2 6 0})$ & MEC $(\mathbf{n = 6 9 )}$ \\
\hline Acute phase & 93 & 89.61 & 98.55 \\
Delayed phase & 85.71 & 85.76 & 84.05 \\
Overall phase & 85.41 & 84.61 & 84.05 \\
\hline
\end{tabular}

respectively; whereas completed protection was 85.76, 81.15 and $79.61 \%$ in acute, delayed and overall phase respectively. (Tables 1 and 2).

Among those who received MEC regimen $(n=69)$, CR-AP, CR-DP and CR-O was 98.55, 84.05 and 84.05\% respectively; whereas completed protection was 98.55 , 84.05 and $84.05 \%$ in acute, delayed and overall phase respectively. (Tables 1 and 2).

The incidence of no nausea in the overall phase was $77.5 \%$ in enrolled patients, $76.92 \%$ in HEC group of patients and $79.71 \%$ in MEC group of patients. (Table 3).

No significant difference was seen in CR-O $(p=0.85)$, CR-DP $(p=0.70)$ and CP $(p=0.70)$ among patients on HEC and MEC regimen but those on MEC regimen had better $(p=0.01)$ CR-AP as compared to those on HEC regimen. The gender-wise response also showed no difference in the CR-O $(p=0.87)$, CR-AP $(p=0.84)$ and CR-DP $(p=0.75)$ among males and females. The regimen (HEC and MEC) wise comparison also showed no difference in the CR-AP, CR-DP and CR-O among males and females in the study.

\section{Discussion}

NEPA is an oral, single dose fixed dose combination in the management of CINV. The FDC consists of new and high selective NK1 receptor antagonist (NK1RA) (Netupitant) and pharmacologically distinct 5HT3 receptor antagonist (5HT3 RA) (Palonosetron). 5HT3 and NK1 receptor pathways are important in the pathophysiology of CINV, and are responsible for the acute and delayed phases respectively $[2,4]$. All the current guidelines, i.e. MASCC/ESMO, ASCO and NCCN recommend the use of 5HT3 RA in the control of the acute phase, and NK1RA in the control of the delayed phase [6-8].

Netupitant is a highly selective and potent NK1 RA with a longer half-life $(\mathrm{t} 1 / 2=96 \mathrm{~h})$ and has higher

Table 2 Complete protection among enrolled patients $(n=329)$

\begin{tabular}{llll}
\hline Phases & \multicolumn{3}{l}{ Complete protection (\%) } \\
\cline { 2 - 4 } & $\begin{array}{l}\text { Enrolled patients } \\
(\mathbf{n}=\mathbf{3 2 9})\end{array}$ & HEC $(\mathbf{n = 2 6 0 )}$ & MEC $(\mathbf{n = 6 9 )}$ \\
\hline Acute phase & 88.44 & 85.76 & 98.55 \\
Delayed phase & 81.76 & 81.15 & 84.05 \\
Overall phase & 80.54 & 79.61 & 84.05 \\
\hline
\end{tabular}

Table 3 No nausea among enrolled patients $(n=329)$

\begin{tabular}{llll}
\hline Phases & \multicolumn{3}{l}{ No nausea (\%) } \\
\cline { 2 - 4 } & $\begin{array}{l}\text { Enrolled patients } \\
(\mathbf{n = 3 2 9 )}\end{array}$ & HEC $(\mathbf{n = 2 6 0 )}$ & MEC $(\mathbf{n = 6 9 )}$ \\
\hline Acute phase & 86.01 & 83.46 & 94.20 \\
Delayed phase & 78.79 & 78.07 & 79.71 \\
Overall phase & 77.50 & 76.92 & 79.71 \\
\hline
\end{tabular}

receptor occupancy as compared to other NK1RA. A positron emission tomography (PET) study conducted to determine the receptor occupancy of netupitant, reported, the $\mathrm{RO}$ is long lasting and in the study $300 \mathrm{mg}$ was the lowest dose tested reaching the 90\% RO $[9,12]$. Palonosetron, a distinct second generation 5HT3 RA, has a unique pharmacological property of receptor internalisation, allosteric binding and the ability to inhibit crosstalk signalling between $5 \mathrm{HT} 3$ and NK1 receptor. In comparison to the first generation 5HT3 RA, it has a 30fold higher affinity and significantly longer half-life [13]. When used in combination, netupitant and palonosetron (NEPA), various in-vitro studies have highlighted synergistic effect in the inhibition of substance $\mathrm{P}$ mediated stimulation of NK1 receptor [14] and additive effect on NK1 receptor internalisation [15]. This synergistic action of NEPA was believed to improve the delayed phase of nausea-vomiting which is the current challenge in the management. In addition, the dose of dexamethasone, a CYP3A4 substrate, should be reduced when used along with NEPA as netupitant is a moderate inhibitor of the cytochrome P450 isoenzyme 3A4 (CYP3A4) [16]..

The safety and efficacy of NEPA was evaluated in three pivotal registration trials [1 phase II and 2 phase III] conducted in chemo naïve patients on HEC and MEC regimens. In all the trials, NEPA was administered approximately 60mins prior to chemotherapy. In two efficacy based pivotal trial by Hesketh P [17] and Aapro M [18], the overall complete response (CR) was 89.6 and $74.3 \%$ respectively. Thus the result of our study i.e. CR rate of $85.41 \%$ is in line with study conducted by Hesketh P [17] and Aapro M [18]. The third pivotal, phase III safety study, conducted by Gralla $\mathrm{R}$ [19], reported as secondary endpoint, $81 \% \mathrm{CR}$ in total population, $84 \%$ CR in the subset of patients on HEC regimen and $80 \%$ in patients on MEC regimen. Our study is in line with the result of above study, where the $C R$ in patients on HEC and MEC regimen was 84.61 and $84.05 \%$ respectively. Another registration trial conducted in Chinese patients by Zhang L [20], too, reported CR in the same range, i.e. $73.8 \%$ in the overall phase and 84.5 and $77.9 \%$ in the acute and delayed phase. Thus the overall CR in the above studies ranges from 73 to $90 \%$.

The commonly prescribed HEC regimen in our study was cisplatin and anthracycline-cyclophosphamide 
based, and the commonly prescribed MEC regimen was FOLFOX or FOLFIRI. The treatment with NEPA thus had overall good control in both the HEC and MEC regimens, because it follows the guideline [6-8] recommendation of using 5HT3 RA for acute phase and NK1RA for delayed phase in patients on the HEC and MEC regimens with associated risk factors.

Despite much advancement in the recent years, nausea is still considered the most bothersome symptom, many patients grade nausea over vomiting as the worst side effect of chemotherapy and delayed nausea to be more troublesome than acute nausea [21]. The biggest problem highlighted with nausea is its subjective nature and hence difficult to define and control. Also, many of the clinical trials have not considered nausea in the primary or secondary endpoint. Our study recorded nausea on a VAS of $100 \mathrm{~mm}$ and the incidence of no significant nausea $(<25 \mathrm{~mm})$ was used for further analysis to determine complete protection. The overall $\mathrm{CP}$ in our study was $80.54 \%$ with better CP in patients on MEC $(84.05 \%)$ than in the HEC (79.61\%) regimen. Complete absence of nausea was reported in $77.5 \%$ enrolled patients in our study. The dose ranging study by Hesketh $P$ [17] reported that with $300 \mathrm{mg}$ netupitant, the overall CP rate was $83 \%$, which was similar to our study, whereas $\mathrm{CP}$ in our study was much better than the study conducted by Aapro $M$ [18] in AC regimen patients, where CP reported was $63.8 \%$ in enrolled patients. The above results with our study and two pivotal studies indicate that NEPA had good control of nausea. This can be because of the synergistic action of palonosetron and netupitant in the prevention of cross talk phenomenon, additive effective of receptor internalisation and higher and longer receptor occupancy of netupitant.

In India, the current management includes the use of aprepitant or fosaprepitant as a NK1 RA. Fosaprepitant, as a single IV dose of $150 \mathrm{mg}$ on day 1 or a 3 -day dosing regimen of oral aprepitant ( $125 \mathrm{mg}$ on day $1,80 \mathrm{mg}$ on days 2 and 3). A phase III RCT conducted by Maru A [22] on Indian subset of population on cisplatin based regimen reported CR-O of 77.1 and $73.4 \%$ with fosaprepitant and aprepitant arms respectively, with CR-AP as 94.2 and $90.1 \%$ and CR-DP as 77.7 and $73.9 \%$ in fosaprepitant and aprepitant arms respectively. Though a double blinded RCT comparing NEPA with Aprepitant/ Fosaprepitant will highlight the superiority of the regimen, the initial report with this indirect comparison suggests NEPA as a better option to the available NK1RA, especially with its effectiveness in managing the delayed phase of nausea vomiting and compliance associated with its use.

The importance of having an effective and safe control of nausea-vomiting in chemonaive patients on the first cycle of chemotherapy was highlighted in study conducted by Molassiotis A [23], where poor control in the first cycle was associated with almost 6.5 times the risk of CINV in the second cycle and almost 14 times in the third cycle. This is because of the anticipatory effect associated to poor control in the previous cycle, which becomes difficult to manage.

\section{Conclusion}

The single oral dose of NEPA targeting dual pathways showed effective control of nausea-vomiting in patients on the HEC and MEC regimens. Its synergistic effect had good control over nausea in both the delayed and the overall phase. The single oral will help in improving compliance with the already complex antiemetic regimen and thus with the anti-cancer therapy. This can also help in improving the guideline adherence in the therapy.

\section{Abbreviations}

CINV: Chemotherapy-Induced Nausea Vomiting; NEPA: Netupitant 300 mg + Palonosetron 0.50 mg; HEC: Highly Emetogenic Chemotherapy;

MEC: Moderately Emetogenic Chemotherapy; FDC: Fixed-dose combination; NK1RA: Neurokinin-1 Receptor antagonist; 5HT3RA: 5-hydroxytryptamine 3 receptor antagonist also known as serotonin receptor antagonists; CRAP: Complete response in Acute Phase; CR-DP: Complete response in Delayed Phase; CR-O: Complete response in Overall Phase; CP-AP: Complete Protection in Acute Phase; CP-DP: Complete Protection in Delayed Phase; CP-O: Complete Protection in Overall Phase; RCT: Randomised Controlled Trial; VAS: Visual Analogue Scale; NSN: No Significant Nausea

\section{Acknowledgements \\ Not applicable.}

Permission to access raw data

Not required.

\section{Patient consent for publication}

Since this was a retrospective study patients consent was not applicable.

\section{Authors' contributions}

BV, PD collected and collated the data. SB, SP, HB helped in the data analysis and manuscript writing. All the authors helped in final draft of manuscript. All authors have contributed to, read and approved the final manuscript for submission.

\section{Funding}

Nil.

\section{Availability of data and materials}

The datasets used and/or analysed during the current study available from the corresponding author on reasonable request.

\section{Declarations}

\section{Ethics approval and consent to participate}

The study was initiated after taking approval from ethics committee and since this was a retrospective study, inform consent from patients was not applicable. (Ethics Committee: St. Theresa's Hospital, A Unit of St. Theresa's Convent Society. Sanathnagar, Hyderabad; Study No: AKY/2019/01).

Consent for publication

Not applicable. 


\section{Competing interests}

Dr. Sagar Bhagat, Dr. Saiprasad Patil and Dr. Hanmant Barkate are employees of Glenmark Pharmaceutical and had helped in the data analysis and manuscript writing.

\section{Author details}

'Consultant Oncologist and Hematologist, Yashoda Cancer Institute, Secunderabad, India. ${ }^{2}$ Consultant Oncologist and Hematologist, Omega Hospital, Hyderabad, India. ${ }^{3}$ Medical Services, IF, Glenmark Pharmaceutical limited, B D Sawant Road, Andheri [East], Mumbai 400099, India.

\section{Received: 9 July 2020 Accepted: 11 May 2021}

Published online: 25 May 2021

\section{References}

1. Janelsins MC, Tejani MA, Kamen C, Peoples AR, Mustian KM, Morrow GR. Current pharmacotherapy for chemotherapy-induced nausea and vomiting in cancer patients. Expert Opin Pharmacother. 2013;14(6):757-66. https://doi. org/10.1517/14656566.2013.776541.

2. Ranganath $P$, Einhorn L, Albany C. Management of Chemotherapy Induced Nausea and Vomiting in patients on multiday Cisplatin based combination chemotherapy. Biomed Res Int. 2015;2015:943618.

3. Dranitsaris G, Molassiotis A, Clemons M, Roeland E, Schwartzberg L, Dielenseger $P$, et al. The development of a prediction tool to identify cancer patients at high risk for chemotherapy-induced nausea and vomiting. Ann Oncol. 2017;28(6):1260-7. https://doi.org/10.1093/annonc/mdx100.

4. Navari RM, Aapro M. Antiemetic prophylaxis for chemotherapy-induced nausea and vomiting. N Engl J Med. 2016;374(14):1356-67. https://doi.org/1 0.1056/NEJMra1515442.

5. Aapro M. CINV: still troubling patients after all these years. Support Care Cancer. 2018;26(1):S5-9.

6. National Comprehensive Cancer Network (NCCC) NCCN clinical practice guidelines in oncology. Antiemesis Version 2. 2018. Available at: www.nccn. org/professionals/physician_gls/pdf/antiemesis.pdf. Accessed on 1 Sep 2019.

7. Roila F, Molassiotis A, Herrstedt J, Aapro M, Gralla RJ, Bruera E, et al. Participants of the MASCC/ESMO consensus conference Copenhagen 2015. 2016 MASCC and ESMO guideline update for the prevention of chemotherapy- and radiotherapy-induced nausea and vomiting and of nausea and vomiting in advanced cancer patients. Ann Oncol. 2016;27(5): v119-33. https://doi.org/10.1093/annonc/mdw270.

8. Hesketh PJ, Kris MG, Basch E, Bohlke K, Barbour SY, Clark-Snow RA, et al. Antiemetics: American Society of Clinical Oncology clinical practice guideline update. J Clin Oncol. 2017;35(28):3240-61. https://doi.org/10.1200/ JCO.2017.74.4789.

9. Hesketh PJ, Aapro M, Jordan K, Schwartzberg L, Bosnjak S, Rugo H. A review of NEPA, a novel fixed antiemetic combination with the potential for enhancing guideline adherence and improving control of chemotherapyinduced nausea and vomiting. Biomed Res Int. 2015;2015:651879.

10. Aapro M, Karthaus M, Schwartzberg L, Bondarenko I, Sarosiek T, Oprean C, et al. NEPA, a fixed oral combination of netupitant and palonosetron, improves control of chemotherapy-induced nausea and vomiting [CINV] over multiple cycles of chemotherapy: results of a randomized, doubleblind, phase 3 trial versus oral palonosetron. Support Care Cancer. 2017; 25(4):1127-35. https://doi.org/10.1007/s00520-016-3502-x.

11. Hsieh RK, Chan A, Kim HK, Yu S, Kim JG, Lee MA, et al. Baseline patient characteristics, incidence of CINV, and physician perception of CINV incidence following moderately and highly emetogenic chemotherapy in Asia Pacific countries. Support Care Cancer. 2015;23(1):263-72. https://doi. org/10.1007/s00520-014-2373-2

12. Spinelli T, Calcagnile S, Giuliano C, Rossi G, Lanzarotti C, Mair S, et al. Netupitant PET imaging and ADME studies in humans. J Clin Pharmacol. 2014;54(1):97-108. https://doi.org/10.1002/jcph.198.

13. Navari RM. Profile of netupitant/palonosetron [NEPA] fixed dose combination and its potential in the treatment of chemotherapy-induced nausea and vomiting (CINV). Drug Des Devel Ther. 2014;9:155-61.

14. Stathis M, Pietra C, Rojas C, Slusher BS. Inhibition of substance P-mediated responses in NG108-15 cells by netupitant and palonosetron exhibit synergistic effects. Eur J Pharmacol. 2012;689(1-3):25-30. https://doi.org/10.1 016/j.ejphar.2012.05.037.
15. Thomas AG, Stathis M, Rojas C, Slusher BS. Netupitant and palonosetron trigger NK1 receptor internalization in NG108-15 cells. Exp Brain Res. 2014; 232(8):2637-44. https://doi.org/10.1007/s00221-014-4017-7.

16. Giuliano C, Lovati E, Funk C, Potthast M, Pietra C. In vitro drug-drug interaction studies with the antiemetic drug netupitant and its major metabolites [M1 and M2], involving main human cytochrome P450 isoenzyme. Ann Oncol. 2012;23(9):ix499-527.

17. Hesketh PJ, Rossi G, Rizzi G, Palmas G, Alyasova A, Bondarenko I, et al. Efficacy and safety of NEPA, an oral combination of netupitant and palonosetron, for prevention of chemotherapy-induced nausea and vomiting following highly emetogenic chemotherapy: a randomised doseranging pivotal study. Ann Oncol. 2014;25(7):1340-6. https://doi.org/10.1 093/annonc/mdu110.

18. Aapro M, Rugo H, Rossi G, Rizzi G, Borroni ME, Bondarenko I, et al. A randomized phase III study evaluating the efficacy and safety of NEPA, a fixed-dose combination of netupitant and palonosetron, for prevention of chemotherapy-induced nausea and vomiting following moderately emetogenic chemotherapy. Ann Oncol. 2014;25(7):1328-33. https://doi. org/10.1093/annonc/mdu101.

19. Gralla RJ, Bosnjak SM, Hontsa A, Balser C, Rizzi G, Rossi G, et al. A phase III study evaluating the safety and efficacy of NEPA, a fixed-dose combination of netupitant and palonosetron, for prevention of chemotherapy-induced nausea and vomiting over repeated cycles of chemotherapy. Ann Oncol. 2014;25(7):1333-9. https://doi.org/10.1093/annonc/mdu096.

20. Zhang L, Lu S, Feng J, Dechaphunkul A, Chang J, Wang D, et al. A randomized phase III study evaluating the efficacy of single-dose NEPA, a fixed antiemetic combination of netupitant and palonosetron, versus an aprepitant regimen for prevention of chemotherapy-induced nausea and vomiting (CINV) in patients receiving highly emetogenic chemotherapy (HEC). Ann Oncol. 2018;29(2):452-8. https://doi.org/10.1093/annonc/mdx698.

21. Hernandez Torres C, Mazzarello S, Ng T, Dranitsaris G, Hutton B, Smith S, et al. Defining optimal control of chemotherapy-induced nausea and vomiting-based on patients' experience. Support Care Cancer. 2015;23(11): 3341-59. https://doi.org/10.1007/s00520-015-2801-y.

22. Maru A, Gangadharan VP, Desai CJ, Mohapatra RK, Carides AD. A phase 3, randomized, double-blind study of single-dose fosaprepitant for prevention of cisplatin-induced nausea and vomiting: results of an Indian population sub analysis. Indian J Cancer. 2013;50(4):285-91. https://doi.org/10.4103/001 9-509X.123580.

23. Molassiotis A, Lee PH, Burke TA, Dicato M, Gascon P, Roila F, et al. Anticipatory nausea, risk factors, and its impact on chemotherapy-induced nausea and vomiting: results from the pan European emesis registry study. J Pain Symptom Manag. 2016;51(6):987-93. https://doi.org/10.1016/j.jpa insymman.2015.12.317.

\section{Publisher's Note}

Springer Nature remains neutral with regard to jurisdictional claims in published maps and institutional affiliations.

\section{Ready to submit your research? Choose BMC and benefit from:}

- fast, convenient online submission

- thorough peer review by experienced researchers in your field

- rapid publication on acceptance

- support for research data, including large and complex data types

- gold Open Access which fosters wider collaboration and increased citations

- maximum visibility for your research: over $100 \mathrm{M}$ website views per year

At BMC, research is always in progress.

Learn more biomedcentral.com/submissions 